\title{
EUPTOIETA CLAUDIA IN MANITOBA
}

WALTER KRIVDA, Box 864, The Pas, Manitoba.

Klots in his Field Guide to the Butterflies mentions that Euptoieta claudia is scarce even in Minnesota. He was evidently unaware of its occurrence in Manitoba.

Most of my collecting experience is centered at The Pas, Manitoba where I have collected intensively since 1950. I took Euptoieta claudia early in my collecting here. Then, as now, it is a sporadic catch dependent on how strong the spring migration of female Euptoieta claudia was from the south.

The species evidently cannot over winter here as an adult and there may well be a return migration southward-yet unrecorded-resembling the monarch in this regard.

Euptoieta claudia is evidently widely distributed in Manitoba but its range is yet unknown. It may extend a long way northward as native violets of various species reach tree-line and beyond. The number of frost-free days may be the determining and restricting factor. It has tropical affiliations and its close relative Euptoieta hegesia, is common enough in Mexico. This may be an additional clue to the idea that all butterflies were originally tropical and radiated into other areas of the planet with time, food and parasite pressures, and climatic changes allowing for survival of adaptive genes. Summarily it can be said that Euptoieta claudia is a migrant into our area from the southern United States. Battered females arrive in the spring on the prevailing south winds in an apparently small migratory phase. They lay eggs on wild violets or evidently, more commonly on garden pansy. The pupal period is brief (as in the Tropics) and a larg Manitoba-produced form emerges July. A hot summer will produce nic specimens as far north as The Pas Cool moist summers tend to produc larger and darker forms. I hav specimens going back to the mio 1950 's that tend to illustrate this.

During the early 1960's I was Par Naturalist at Riding Mountain Natione Park with headquarters Wasagaming, Manitoba. In the cours of routine work various butterfl observations were made-includin positive evidence that Euptoiet claudia breeds in Manitoba.

Excerpts from my field notes follon Wasagaming, Manitoba July 20, 1964

"Today at the Forestry Nursery Station watched a female Euptoieta claudia la eggs on garden pansy plants. Also neark I found two second instar larvae on ver small pansy seedlings. They have tw tufted horns at the front and are varie gated brownish. They rested parallel one another. The female, while layin placed the eggs singly one to a pans seedling. She was rather battered and I di not have the heart to collect her, engage as she was in motherhood, an America invention. These larvae should produc adults in 3-4 weeks time. This is the firs time that I have seen the species laying.

Wasagaming, Manitoba July 23,1964

"Today, near the Information Office i the Park, I saw a very large, fresh an darkish looking specimen of Euptoiet claudia. This must have come from th earliest laid eggs-perhaps in early June There is thus an apparent overlap i appearance of fresh specimens on th wing." 
lasagaming, Manitoba

ugust 7,1964

"On August 2, 1964 I found an Eupieta claudia like larvae eating pansies in flower window box of the bunk house in wn. This was in its last instar. It pupated ugust 4. I am not certain that this is Eupieta claudia, so am eagerly awaiting its mergence. If it is Euptoieta claudia this ill confirm my idea that there is a final mallish terminal brood on the wing at the nd of August and running into early eptember. This is the last brood and is haracteristically smaller. Some large becimens taken at The Pas in July 1956 dicate the larger summer generation. his small form possibly does not occur at he Pas in the autumn."
Wasagaming, Manitoba

August 14, 1964

"Emerged in the afternoon a good specimen of Euptoieta claudia. The specimen and pupal case preserved. Pupal period: 12 days."

Wasagaming, Manitoba

August 16, 1964

"Today I saw a large, fresh Euptoieta claudia at the window box where the pansies are grown. It moved too swiftly to determine the sex. It flew 30 feet straight up and over the building and was away."

The above data is likely the first on the biology of this butterfly species in Manitoba. Its sporadic appearance and infrequent capture may have precluded previous observations on its biology.

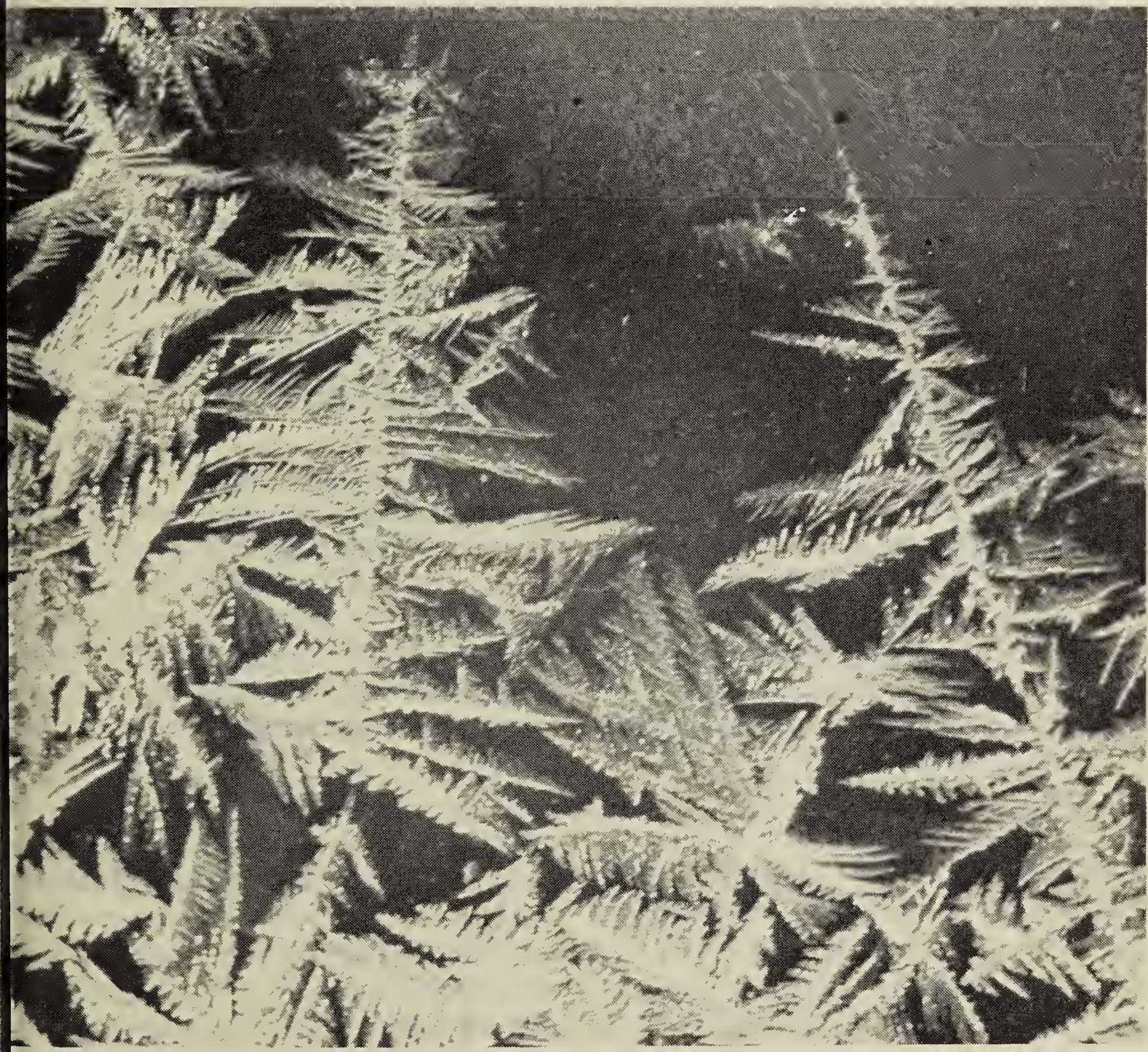

